\title{
The Project Physics Course, Then and Now
}

\section{Citation}

Holton, Gerald. 2003. The Project Physics Course, Then and Now. Science and Education 12 (8):

779-786. doi: 10.1023/B:SCED.0000004544.55635.40

\section{Published Version}

10.1023/B:SCED.0000004544.55635.40

\section{Permanent link}

http://nrs.harvard.edu/urn-3:HUL.InstRepos:37852650

\section{Terms of Use}

This article was downloaded from Harvard University's DASH repository, and is made available under the terms and conditions applicable to Other Posted Material, as set forth at http:// nrs.harvard.edu/urn-3:HUL.InstRepos:dash.current.terms-of-use\#LAA

\section{Share Your Story}

The Harvard community has made this article openly available.

Please share how this access benefits you. Submit a story.

Accessibility 


\title{
The Project Physics Course, Then and Now
}

\author{
GERALD HOLTON \\ Jefferson Physical Laboratory \\ Harvard University \\ Cambridge, MA 02138 \\ E-mail: holton@physics.harvard.edu
}

I have been asked to speak today (at this November 2001 Annual History of Science Society meeting), as the program has it, on "The Project Physics Course, Then and Now." I do so gladly, but must alert you that it is the story of a roller-coaster ride--up, down, and up again, as you will see. In its first few editions, Project Physics was a nation-wide physics course at the introductory level for high-school students in the United States, as well as in colleges. What this audience may want to know most about is no doubt the way in which the design of the course, in addition to physical science itself, used the history and methodologies of science and the interaction of science and society. I will come to that shortly. But this will be better understood if I say first something about the history by which Project Physics came about, and even what its intended future is.

\section{Beginnings}

It all started very innocently, and as so often in life, with consequences one could not have foreseen. In 1962, a visitor came into my office at Harvard University's Physics Department. I had not met him. The young man had an engaging personality, getting his doctorate at Harvard from the Graduate School of Education under Professor Fletcher Watson, who long before had been persuaded by President Conant to change from a professor of astronomy to professor of science education, so as to bolster the Education School in that department.

My visitor was James Rutherford, on leave from his position as physics teacher and science supervisor at a high school in California. He came to me with a proposal. As a text for his physics class back home, he had been using my first textbook, titled Introduction to Concepts and Theories in Physical Science. What had attracted him to it was that it was not the usual, narrowly conceived text, but included other sciences, primarily astronomy and chemistry; that it used the history of science throughout, from the ancient Greeks and Copernicus to current nuclear physics; and that it also had some philosophy of science--three chapters on the structure and methods in physical science. In writing the book I had had in mind that in this one course a college student might take in physical science, one really must present not only good science, but also something solid on the way science is done and grows, on the scientific worldview, on how the sciences are interrelated with one another and with world history itself.

At any rate, Rutherford's proposal was that I should sit down and write a version of my book that would be more suited to the reading level of a typical high-school student. But I was of course otherwise occupied: there was my teaching load; running the research group in my high-pressure laboratory; and also publishing in the history of science. So I asked my visitor: "Why don't you do it?" Well, eventually we agreed that he would try, and I would monitor it. A small grant from the Carnegie Corporation and one from the Sloan Foundation bought him time to do it. And that would have been the end of it. 


\section{National Science Foundation}

But all this occurred not so long after the launching of Sputnik. Thus, in the following year I received an emergency call to come to the National Science Foundation in Washington, where I found myself among some thirty or so science-educators from all over the U.S. We were implored by the NSF officials to throw ourselves, individually or in groups, into the awesome task of designing, writing, testing, re-editing and finally publishing a national high-school physics course. One such had existed for years, the PSSC course designed under Jerrold Zacharias of MIT. But for various reasons, it had attracted only about $4 \%$ of the two and a half million senior students in high school, and the total fraction taking any physics course was under $20 \%$, and relatively shrinking.

This was ominous, since a physics course is advisable, at the very least, for future career decisions, not only in science but in medicine and other professions, in policymaking at a time when about half the cases facing Congress or the courts or even ballot questions have a strong scientific/technical component. In chemistry, biology and mathematics, there had been published at least two such national courses for each. Physics so far had only one. At least one other course was needed. Therefore we were asked by the NSF officials there: who among us would come to the aid of the country? For, it was thought in those days, without more science-literate students the Russians might get us.

Everyone at that meeting was sensible enough to say, "no." Except one. And that's how I became the principal investigator of what we first called Harvard Project Physics-later changed to the Project Physics Course (because we discovered that the word "Harvard" was thought to sound - I hardly know why - as too elitist in parts of the country distant from Harvard Square).

I had agreed, chiefly because I saw the opportunity to have a humanistic, historically oriented course available for schools, one that would regard physics, as in my original text, not just as one damnded thing after another, but a coherent story of the result of the thoughts and work of living beings. (I have written some articles on the philosophy behind the Project Physics Course; they are listed in the bibliography.)

Jim Rutherford and Fletcher Watson were quickly persuaded to join me, to form a troika to run the thing. In fact that was an ideal combination-Jim, an excellent, experienced high school teacher; Fletcher, a top science educator who would take on, for example, the evaluation of the several pilot editions revised, year by year, for several years; and myself, to keep an eye on getting the physics and history of science right. Parenthetically, I should say that the National Science Foundation was not pleased when it woke up to the fact that the course wasn't going to be only "pure" physics, and--horror upon horror--would be co-directed by a science teacher, even would eventually engage a large number of teachers in the revisions, tryouts and running institutes for teacher education. (It has long since changed its ways.)

\section{Textbook}

In the text we developed there is quite enough physics in the six main units of the book.

But it includes much more, for example, special sections on the way advances in thermodynamics helped lead to the first industrial revolution; similarly, how Faraday's "toys" helped in starting the second, electrical industrial revolution; and the effect of $E=\mathrm{mc}^{2}$ on the eventual building of nuclear reactors, weapons, and isotopes for medical research.

The book was thoroughly illustrated, frequently from history of science documents, starting with the crucial page in Copernicus's De Revolutionibus, obtained directly from the University of Krakow library, and ending with the Medical Research Center at the Brookhaven accelerator. I thought it of greatest importance that the book's accuracy and ambition should be 
reflected in the excellence of its design throughout. Therefore one of the first persons persuaded to join our project was the superb designer, Albert Gregory.

Even a brief look at the index of the text would indicate the interconnections we tried to forge between physics, its neighboring sciences, its history, its cultural context, its effects. Another way to indicate the role of history and philosophy of science we embraced is by looking at the names of some of the 180 people whom we involved over the many years of development of the course and its components, not counting the teachers in dozens of trial schools $(53$ such schools the first time, over 100 the next year, and so forth, involving eventually a total of about 10,000 students in the tryouts of the revised editions). The Advisory Board included Erwin Hiebert of Harvard, Philip Morison of MIT, and Ernest Nagel and I. I. Rabi, both of Columbia University. Among the 120 people we persuaded to work with us at Harvard, some for one or more years, some more briefly, were persons some of whose names you might recognize and whose role you can safely guess: Arnold Arons, O. Theodore Benfey, Stephen G. Brush, Robert S. Cohen, Owen Gingerich, June Goodfield, Banesh Hoffmann, Edwin M. Purcell, John Rigden, Katherine Sopka, and Stephen Toulmin

\section{Other Materials}

Writing just a good textbook would have been relatively easy. But in those affluent and ambitious days, when curriculum development could be funded, when schools could afford to buy, or were freely given by us, the materials, and when one could assume a greater attention span from students, publishing a text was not enough. Of course, we had to develop and provide also a rather elaborate student handbook and a fat instructor's guide. So a varied and large- - by today's standards, an astounding — set of ancillary course components, including laboratory apparatus, had to be developed and tested by us as well, and suppliers had to be found who would make all of these materials available, so to speak at the push of a button, or as we would say in those days, by distributing a catalog similar to that of Sears Roebuck, from which to place the orders.

Our 42-page catalog of materials included of course a brief description of the student text and student handbook. There were also test booklets for each of the units. At first we tried to have no multiple-choice test questions and only essay questions; but the teachers rebelled, and so we had to include some of those hated multiple-choice tests after all.

We had made available programmed instruction booklets; some supplemental units going beyond those covered in the six units of the text; forty-six projectable transparencies; fortynine $8 \mathrm{~mm}$ film loops, each about three minutes long, of actual phenomena (for example, how a boat crosses a river that has a strong current--a vector problem); twenty-one teacher training films; a wealth of laboratory materials and equipment specially designed for each unit of the course; and three $16 \mathrm{~mm}$ sound films: a short one on how a cyclotron works, by recording an actual visit to one; then a class-length film called "People and Particles," in which I wanted to show how an experiment is done by a team making an experimental test of Quantum Electrodynamics, starting from their first meeting to the final results. (That documentary, by the way, was entered behind our backs by the State Department at various foreign film festivals, and it won, believe it or not, among its awards, first prize at a Science Fiction Festival!)

But perhaps most interesting was our third film, "The World of Enrico Fermi," a twoyear, separate effort, following the life and work of Fermi and his time, by interviewing his collaborators in Italy and the United States, and using all film clips of him that had survived his

death in 1954. I wanted students to see the work and life of a distinguished $20^{\text {th }}$-century scientist, and the effects on world history. It was finished in the early 1970s, at a time when there were no such films available.

And there was one more component in the set of course materials: what we called Readers: books of readings, for each of the units, the content ranging from biography to 
engineering applications to poems referring to science. One reason for all this multimedia cornucopia was to let each teacher decide what part to use for the class, and what medium to use for a given subject and class. For example, some materials in the text could be learned best from the lab or a demonstration in class, or with the help of a film loop of the phenomenon (such as a boat crossing a river).

By now, an obvious problem will have occurred to you: How in heaven's name can a teacher handle all this wealth with his or her usual mediocre or even good preparation? The instructor's handbook laid out day-by-day schedules of various sorts, even provided detailed solutions to the student text problems, gave the background for each of the components, how to do the laboratories and demonstrations, etc. It also provided help with following the flow of concepts, discussion of background and content of the film loops and our three longer films, and so forth. Moreover, it showed how to select among the various components, depending on the teacher's ideas and circumstances. But the key for most such teachers was to take a paid-for leave to go to a six- to eight-week summer institute at one of the many teacher training sites in various parts of the country, which we organized for many years. Thousands of teachers went through those - great for them, but as you can imagine, an additional burden above all on Jim Rutherford, who acted tirelessly throughout the project as its Executive Director.

\section{Utilization and Impact}

So what came of it? I have time to mention just four points. After the final edition was published by Holt, Rinehart \& Winston in 1970, as many as 300,000 students per year were taking all or some significant part of the course materials. This meant, secondly, that the percentage of students taking physics, particularly among women students, increased markedly, with some $20 \%$ of all high school students taking Project Physics, and use also in some colleges. Next, we carefully monitored a worrisome point, namely, that students in our course might in the end be exposed to tests like the Regent's Examinations of New York, which presumed a rather different sort of physics course - one that might have no general view of physics as a part of the greater culture, but rather would ask about, let us say, the exact path of light rays through a threelens system, or the electric current in one branch of a complex set of resistors, capacitors and coils - none of which loomed large in our text. It turned out that on average our students did as well or actually somewhat better than other physics students on such external tests, even if they had to skip a few questions in it. The evaluation groups, working from the early 1960s to the early 1970s, many under Fletcher Watson's direction, turned out over sixty published articles, research papers and reports, fifteen doctoral theses or qualifying papers, all based on studying the results of Project Physics. Two dozen more analyses were published by people not associated with Project Physics. If you want to look at just a single overview article, see Andrew Ahlgren and Herbert Walberg's, listed in the bibliography.

The course text and some of its ancillary materials were published in translated versions abroad. But in each case we demanded the opposite of some of the other U.S. national science courses; that is, we made our materials completely available, on condition that a local group be set up in each particular country, to adapt the course material to the local conditions, conditions both of the educational system and of the culture of the country.

Thus, there appeared local versions of Project Physics in various countries; some of these programs are doing well to this day. They were made, among other countries, in Italy, Portugal, Japan, China, Australia and Canada--yes, the English versions in those two countries also had to be redone locally. And sometimes where they did not seem to us to pass muster, being too close or too different, we allowed them to use whatever they wanted as long as they would not associate it with Project Physics.

\section{Subsequent History and Present Revival}


A word now about the downside part of the roller coaster, and then the promising new upswing. By about 1973, President Richard Nixon had become disenchanted with scientists who, on the whole (including members of his Presidential science advisory body) seemed hostile to his policies, especially on Vietnam. As the saying goes, when elephants move, small fry get squashed. One byproduct of Nixon's displeasure was a phasing-out of sections of federal science funding; the money for teacher training was fairly soon cut off.

With that, it was much more difficult for us to have a very large effect on the educational system. After the 1970 edition, there had been thorough revisions, the last revised edition being published in 1981, and in fact it is still being used here and there to this day. Parenthetically, I may add that after 1981 Harcourt Brace, then having become Harcourt-Brace-Javonovich (which had previously absorbed our initial publisher, Holt, Rinehart \& Winston), could not see itself doing even a revision of a narrower set of materials, because of its precarious financial condition resulting from an attempted hostile corporate merger.

Still, for Project Physics there has remained all these years a remarkable number of loyal users and friends. And this is why the course, like that sleeping princess in the fairy story, lately has been waking up again. This new awakening has resulted from the conjunction of several conditions. Over the years, we have been implored by teachers who have been loyal to the course, to make an updated version available. Moreover, we now face the fact in the U.S. that over the next few years about two million new high school teachers will have to be found to replace the current wave of retirements and dropouts, among them of course many physics teachers. Most of them will not have taken more than perhaps one college physics course some years ago. They will need a lot of help, such as a carefully constructed teacher guide and a teacher-friendly course. The alternative is that they will have to turn to the kind of high-school texts available now, most of them having sunk back to a narrow, dumbed-down level.

And yet another important incentive for us was that both the American Association for the Advancement of Science's Benchmarks for Science Literacy and the prestigious National Academy of Sciences' report, with the title National Science Education Standards (1996), gave solid backing for the way we think science should be taught. For example, the suggested standards for science content for $\mathrm{K}$ through $12^{\text {th }}$ grade, published by the National Academy, states unequivocally: "In learning science, students need to understand that science reflects its history, and is an ongoing, changing enterprise. The standards for the history and nature of science recommend the use of history of science in school science programs to clarify different aspects of scientific inquiry, the human aspects of science, and the role science has played in the development of various cultures." The Report then shows in detail how this might be done, grade by grade, science by science.

And finally we realize that among our friends there is an ideal person to head the revision of the Project Physics Course, adapted to the new age. It is the physicist and historian of science, Professor David Cassidy at Hofstra University. You may know him as the author of the authoritative biography of Werner Heisenberg, a book which won prizes both as the best book of the history of science of the year and also, at the same time, the award for best science writing from the American Institute of Physics - a unique combination. In his introductory college physics classes, he had been teaching much of the previously published Project Physics materials, and he agreed to take leadership in preparing the new version, the text, the instructor's manual, and the student guide, incorporating new research published over the last decades, both in the history of science and in science. In the new text, there are also special sections on technology, their roots in science, and their social and economic consequences. Jim Rutherford and I have been his co-workers in the preparation of the materials.

All these materials were developed over the past three years, tested in tryout schools and in college use, and re-edited in the light of experience. Springer Verlag-New York released them in August 2002. The name of the text is now simply Understanding Physics. It comes in two 
parts, one of which might be called "Copernicus to Einstein," and the other "From Faraday to Fusion Energy." The reason for doing it that way is that whereas Project Physics was still able to count on a full year of physics in schools and most colleges, today there is often allowed only a half-year course at best. So this two-part arrangement will give the instructor a choice how to proceed, using one or the other or a mix of them.

As before, the Student Guide recommends a good deal of laboratory work, where concepts are taught through actual hands-on experience. And as is appropriate in this new century, the publisher has agreed to put the whole thing on a website. In a satisfying replay of history, the financial support came again from the Carnegie Corporation and the Sloan

Foundation. The Science Education part of the National Science Foundation now has a budget of over \$900 million; so we have high hopes that the NSF will once again help in teacher training.

In short, there is now again an option open for those who care for a humanistic and historical approach physical science. It completes a great circle, spanning exactly four decades, from the first draft in 1962, throughout the onerous but satisfying work done through the Project Physics years of development, through the slough of despond after the early 1980s, and now on to the rising of the new Phoenix.

$$
\text { \# \# \# }
$$

\section{Bibliography}

Ahlgren, Andrew and Herbert J. Walberg. "Changing Attitudes toward Science among Adolescents," Nature, v. 245 (September 28, 1973), 187-190.

American Association for the Advancement of Science. Benchmarks for Science Literacy

(Washington, DC, 1993).

Bevilacqua, Fabio, Enrico Giannetto, and Michael R. Matthews. Science Education and Culture

(Dordrecht: Kluwer Academic Publishers, 2001). See especially the chapters by F. James Rutherford and by Ron Good and James Shymansky.

Cassidy, David, Gerald Holton and James Rutherford. Understanding Physics (New York:

Springer Verlag-New York, 2002).

Holton, Gerald. Introduction to Concepts and Theories in Physical Science (Cambridge, MA:

Addison-Wesley Publishing Co., first edition 1952).

Holton, Gerald. "On the Educational Philosophy of the Project Physics Course, " The Scientific Imagination (Cambridge, MA: Harvard University Press, 1998), pp. 284-299.

Holton, Gerald. "Physics and Culture: Criteria for Curriculum Design," Thematic Origins of Scientific Thought: Kepler to Einstein (Cambridge, MA: Harvard University Press, 1973 edition), pp. 461484.

Holton, Gerald (with Stephen G. Brush). Physics, the Human Adventure (New Brunswick, NJ: Rutgers University Press, 2001).

Holton, Gerald. "Science, Science Teaching, and Rationality," in Paul Kurtz (ed.), The Philosophy of the Curriculum. The Need for General Education (Prometheus Books, 1975), pp. 101-117.

National Academy Press. National Science Education Standards (Washington, DC, 1996). (The Report can be purchased from the National Academy Press at 2101 Constitution Ave., NW, Washington, DC 20055, giving the code SCISTA.)

Matthews, Michael R. Time for Science Education (New York: Kluwer Academic/Plenum Publishers, 2000).

The Physics Teacher. "Harvard Project Physics. A Progress Report," v. 5, no. 5 (May 1967). The Project Physics Course (New York: Holt, Rinehart \& Winston, first edition 1970).

Biographical Note

Gerald Holton is Mallinckrodt Professor of Physics and Professor of History of Science Emeritus, Harvard University. His research in the history of science has resulted in a 
number of books, including The Advancement of Science, and Its Burdens (1986), Thematic Origins of Scientific Thought (1988), Einstein, History, and Other Passions (2000), and (with Stephen G. Brush) Physics, the Human Adventure: From Copernicus to Einstein and Beyond (2001). Among his honors are the Millikan Medal, the George Sarton Medal, election to Fellowship of the American Philosophical Society, the American Physical Society, the presidency of the History of the History of Science Society, and selection by the National Endowment for the Humanities as Jefferson Lecturer. He has been Vice President of the International Academy of the History of Science, and is a member of Deutsche Akademie der Naturforscher Leopoldina, and other international honorary and academic organizations 